\title{
COLD COMFORTS
}

\section{Message from the abyss.}

\section{BY GRAHAM ROBERT SCOTT}

I

$\mathrm{n}$ the recording, the audio kicks in before the video does. Hera hears her son's voice in the background.

"Start a proxy," he says.

She detects a slight tremble, hints of resignation and sorrow. His face appears on the screen then. Haggard, bristly. Rings under brown eyes.

"Who would you like to proxy?" the ship intelligence replies.

"Mum," his voice says with a crack. "Dad."

"Oh, Leo," she says to the screen in her booth. He cannot hear her. He is, or was, almost 3 billion miles away. Which means he hasn't yet heard about his father. Doesn't know his father will never view this message. At current distances, each message takes more than a week to reach its destination.

In the recording, however, it's only a second before the pseudo-intelligent proxies engage.

"Leo!" her own voice says on the recording, incongruously upbeat. "What a pleasant surprise!"

"Hey, champ," says her husband's proxy.

"Uh, hey Mum. Dad," Leo replies.

With the proxies, her son has always been awkward, an ironically poor imitation of himself. He pauses, unable to make eye contact with the camera.

"Son?" her husband's proxy says. "Are you okay?"

Hera sees the slight shake of Leo's head. No. Obviously, he isn't. The proxy version of her, however, misses the cue.

"Did you get our Christmas videos?" the imitation asks.

Insensitive bitch, Hera thinks.

He nods, distracted. "I have some bad news."

There's a strangled, pained, anticipatory sound from the simulated mother. It's a sound of dread and suspense, and uncannily accurate, for the real mother in her booth realizes she made the same sound days ago.

Leo sniffs, long and wet, runs a hand through untamed hair.

"The Graff manoeuvre didn't work."

Proxy Mum gasps. Proxy Dad is barely audible as a low moan.

"But ... That can't be," she hears her voice $\rightarrow$ NATURE.COM

Follow Futures:

@ @NatureFutures

$f$ go.nature.com $/ \mathrm{mtoodm}$ saying.

Leo waits for it to sink in.

"They were so sure!" her voice says.

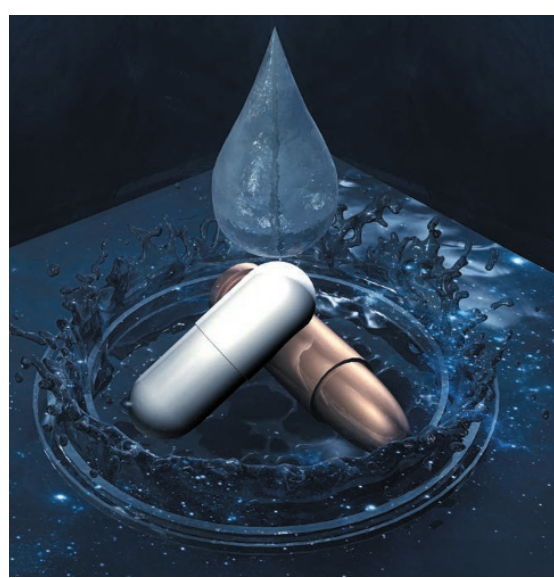

"They said it was a near certainty!"

"Those bastards," her husband's voice grumbles. "I warned them. They dismissed me as out of touch with the latest figures and I bought it. Those cocky bastards.”

"I know it's a surprise," Leo says. "I'm a bit... stunned, too. The odds of failure were low. But they're always there. You know that, Dad."

Proxy Dad says nothing.

"So now what? What's the next step?" her distant voice asks, although the listening mother already knows, had already figured it out from the looks she got as they led her to the booth, and from her husband's death at his own hand, five days earlier, amid pictures of Leo and a storm of scribbled equations.

Leo takes a deep breath. "There isn't one, Mum. I'm not coming home," he says.

The Proxy Mum erupts into shuddering sobs, and the listening mother is disoriented to hear the soundtrack of her soul while her own throat squeezes out almost no sound at all.

Since he sent this message, he's already died, Hera realizes. How did it happen? Did he drift ever lower until crushed and irradiated? Did he find a better way to die?

Proxy Mum has the same question. Or a version of it.

"Wh - what are you going to do?"

"Keep working. Until I can't."

Proxy Dad intrudes: "To hell with that. Don't suffer. Take the pill."

At this, Hera chokes on an involuntary sound, halfway between a sob and a growl. Lacking a pill, her husband had taken a bullet.

"We lost automation in the earlier collision," her son explains. "The only way we're going to get data on the way down is if I run the show by hand."

"So - what? You're going to be awake as you're crushed?" her voice protests.

"I'll take the pill when it's too much to bear."

Her proxy voice is quiet, feeble, when it answers: "But I don't want you to reach that point."

"It's another two minutes after you take it," adds the unsteady voice of Leo's father.

"I know," Leo says.

And then he sits there. His posture reminds the listening mother of times in his childhood when they sat him at the kitchen table, after he had admitted to wrongdoing. It's his Awaiting Judgement Slouch.

Her proxy picks up on it, too.

"I'm so sorry, son," Proxy Mum says. Her voice wavers at first, then strengthens, as if she's summoned the courage to reassure. "We are going to miss you very, very much."

"I miss you already," Leo mumbles.

"I know we resisted your ambitions at first," her proxy continues. "But we are so proud of you. Your accomplishments. Your bravery."

Leo cries.

"You're the best thing that ever happened to me," says her dead husband's voice. "I couldn't have asked for a better son."

Leo sobs.

"I’ve gotta go," Leo sniffs. "Thank you for ... well, everything. I love you, both of you, more than I know how to articulate. And I'm so, so sorry."

He disconnects. The light of the screen winks out, replaced by a dull, flickering grey that isn't quite black, and the booth goes dark.

Leo's widowed mother sits alone. On her end, there is no proxy son.

Outside the booth, 18 people pretend to work. None looks at the booth, but all listen. For a minute, there's silence from the widow and mother inside. Then screaming. Enraged invective and profanity. Employees exchange awkward glances, but no one moves towards the door.

Eventually, someone has to talk to the woman. To a woman who just listened as a ship took her place during her child's last moments, far from home.

But no one wants to be first..

Graham Robert Scott is an English professor and former journalist. He teaches writing and rhetoric at Texas Woman's University. 